\title{
HUBUNGAN PENGETAHUAN TENTANG VAKSIN MR (MEASLES RUBELLA) DAN TINGKAT PENDIDIKAN ORANG TUA TERHADAP KEIKUTSERTAAN IMUNISASI MR DI DESA LAM BHEU, KECAMATAN DARUL IMARAH, KABUPATEN ACEH BESAR
}

\author{
Alisa Putri ${ }^{1}$, Aslinar $^{2}$, Desiana $^{2}$ \\ ${ }^{1}$ Mahasiswa Kedokteran Universitas Abulyatama Fakultas Kedokteran Umum \\ ${ }^{2}$ Dosen Fakultas Kedokteran Universitas Abulyatama
}

\begin{abstract}
Relatoinship Of Knowledge About Mr (Measles Rubella) Vaccine And Parental Education Level To Mr Immunization Participation In Lam Bheu, Village Darul Imarah, District Aceh Besar.

Measles and Rubella are infectious diseases transmitted through the airways caused by the measles and rubella virus. MR vaccine (Measles Rubella) provides benefits such as protecting children from disability and death due to complications of pneumonia, diarrhea, brain damage, deafness, blindness, and congenital heart disease. The 2018 data in Aceh Besar District has $42 \%$ of cases of measles and $61 \%$ of cases of rubella. This study aims to determine the relationship of knowledge about MR vaccine and parental education level to the participation of MR immunization in Lam Bheu, Village Darul Imarah, District Aceh Besar regency. This study was observational analytic with a cross sectional approach. The number of research respondents was 69 respondents with Purposive Sampling techniques. Statistical analysis using Chi Square Test. Research with a total of 69 respondents found high knowledge of high participation interest as much as $95.5 \%$ so obtained value $P<0.05(0,000)$. The results of the study were based on the level of higher education with a high participation interest of $77.3 \%$ so that the value of $p>0.05$ (0.664) is obtained. Based on the research that has been done, it can be concluded that there is a correlation between the knowledge of MR vaccines and the participation of MR immunization but there is no correlation between parental education level and the participation of MR immunization.
\end{abstract}

Keywords :MR Vaccine, Vaccine Interests.

Abstrak: Hubungan Pengetahuan Tentang Vaksin Mr (Measles Rubella) Dan
Tingkat Pendidikan Orangtua Terhadap Keikutsertaan Imunisasi Mr Di Desa
Lam Bheu, Kecamatan Darul Imarah, Kabupaten Aceh Besar. Campak dan Rubella merupakan penyakit infeksi menular melalui saluran nafas yang disebabkan oleh virus Campak dan Rubella.Vaksin MR (Measles Rubella) memberikan manfaat seperti dapat melindungi anak dari kecacatan dan kematian akibat komplikasi pneumonia, diare, kerusakan otak, ketulian, kebutaan, dan penyakit jantung bawaan. Data tahun 2018 di Kabupaten Aceh Besar tedapat 42\% kasus campak dan $61 \%$ kasus rubella. Penelitian ini bertujuan untuk mengetahui hubungan pengetahuan tentang vaksin MR dan tingkat pendidikan orangtua terhadap keikutertaan imunisasi MR di desa Lam Bheu, Kecamatan Darul Imarah, Kabupaten Aceh Besar. Penelitian ini bersifat observasional analitik dengan pendekatan Cross sectional. Jumlah responden penelitian sebanyak 69 responden dengan teknik Purposive Sampling. Analisis statistik menggunakan Uji Chi Square. Penelitian dengan jumlah 69 responden didapatkan hasil pengetahuan tinggi minat keikutsertaan tinggi sebanyak $95,5 \%$ sehingga didapatkan nilai $\mathrm{P}<0.05(0,000)$. Hasil penelitian berdasarkan tingkat pendidikan tinggi minat keikutsertan tinggi sebanyak $77,3 \%$ sehingga didapatkan nilai $p>0.05(0,664)$. Berdasarkan penelitian yang telah dilakukan dapat disimpulkan bahwa terdapat hubugan antara pengetahuan tentang vaksin MR dengan keikutsertaan imunisasi MR akan tetapi 
tidak terdapat hubungan antara tingkat pendidikan orangtua dengan keikutsertaan imunisasi MR.

Kata Kunci :Vaksin MR, Minat Vaksinasi

\section{PENDAHULUAN}

Vaksin Measles Rubella (MR) merupakan vaksinisasi yang digunakan dalam memberikan kekebalan terhadap penyakit campak (measles) dan campak jerman (rubella) (Najah, 2017). Campak dan rubella itu sendiri adalah penyakit infeksi menular yang terjadi melalui saluran nafas yang di sebabkan oleh virus campak dan rubella (Marlinta, 2018). Virus ini cara penularannya melalui batuk dan bersin (WHO, 2017).Gejala dari penyakit campak akan nampak muncul sekitar 10 hari setelah infeksi, dan ruam coklat kemerahan yang muncul tampak sekitar 14 hari setelah infeksi (McGee, 2015).

Gejala penyakit campak di antaranya demam tinggi, bercak kemerahan pada kulit, batuk, pilek, konjungtivitis. Komplikasi dari penyakit campak ini yaitu pneumonia, diare, meningitis, Radang paru, radang otak, kebutaan, radang telinga, dehidrasi dan bahkan kematian (Ditjen P2P Kemenkes RI, 2017).Sedangkan Rubella termasuk penyakit ringan pada anak tetapi dapat memberikan dampak buruk apabila terjadi pada ibu hamil trimester pertama yaitu terjadinya keguguran ataupun kecacatan pada bayi yang sering disebut dengan Congenital Rubella Syndrom (CRS) seperti kelainan jantung, mata, ketulian, dan bahkan keterlambatan perkembangan (Awam, 2017).

Dalam vaksin MR antigen yang di pakai adalah virus campak strain Edmonson yang dilemahkan, virus rubella strai RA $27 / 3$, dan virus gondog (Hidayat, 2018).Vaksin ini diberikan pada anak usia 9 bulan sampai dengan kurang dari 15 tahun (Kemenkes, 2018),tetapi bagi anak yang sebelummya sudah melakukan vaksin campak vaksin MR ini tetap diberikan (UNICEF, 2018). Tujuan pemberian vaksin MR yaitu untuk merangsang terbentuknya imunitas atau kekebalan terhadap penyakit campak, dan rubella (Wawan, 2011). Manfaat pemberian vaksin MR adalah untuk memberikan perlindungan terhadap kedua penyakit tersebut pada saat yang bersamaan (DepKes RI, 2017).

WHO (Word Health Organization) tahun 2015, menyebutkan bahwa Indonesia termasuk 10 negara dengan kasus campak terbesar didunia, ditambah dengan adanya dukungan data dari Kementian Kesehatan pada prevalensi lima tahun terakir sejak 2014 s/d juli 2018 sebanyak 57.056 kasus (8.964 positif campak dan 5.737 positif rubella) (Kesehatan \& Indonesia, 2018). Maka dari itu WHO menganjurkan semua negara harus menerapkan program pemberian vaksin rubella termasuk negara yang sudah memasukkan campak kedalam imunisasi dasar rutin untuk menambah vaksin rubella kedalam imunisasi dasar (Prabandari, 2018).

$\mathrm{Di}$ Indonesia terdapat sekitar lebih dari 11.000 kasus suspek campak dan rubella yang dilaporkan, dari hasil konfirmasi laboratorium confirmed menunjukkan $12-39 \%$ di antaranya positif campak dan $16-43 \%$ positif rubella. Pada data yang diperoleh dari periode tahun 2010-2015 terdapat sekitar 23.164 kasus campak dan 30.463 kasus rubella. Hasil data yang diperoleh ini diperkirakan dilapangan jauh lebih tinggi (WHO, 2018). Data yang diperoleh dari UNICEF di Aceh pada tahun 2017 dilaporkan sekitar 40,507 kasus campak dan rubella dimana 59\% kasus rubella dan 57\% kasus campak (UNICEF, 2017).

Berdasarkan data yang diperoleh dari Dinas Kesehatan Provinsi Nanggore Aceh Darussalam pada Kabupaten Aceh Besar terdapat sekitar 50,719 kasus campak dan rubella dimana $79 \%$ kasus campak dan $82 \%$ kasus rubella pada tahun 2018 (Dinkes Aceh, 2018). Pada data yang diperoleh dari Pukesmas Darul Imarah pada 
tahun 2018 terdapat sekitar 58 anak yang baru melakukan vaksin MR dari 976 anak yang di targetkan untuk vaksin MR. Hal ini menunjukkan masih rendahnya pemberian vaksin $M R$ di desa ini (Puskesmas Di Aceh, 2019). Kebanyakan kasus diatas disebabkan oleh kurangnya peran orangtua, seperti yang kita ketahui orangtua memiliki peran penting dalam pemberian imunisasipada anak agar anak terhindar dari penyakit yang menular. Pemberian vaksin MR banyak tidak dilakukankarena beberapa faktor diantaranya pengetahuan, pendidikan, pekerjaan, sikap, penghasilan, dukungan keluarga, dan dukungan petugas tinggi kesehatan. Disini pengetahuan dan pendidikansangat berperan penting dalam pemberian imunisasi karena mampu mempengaruhi sikap orang tua dalam pengambilan keputusan terhadap pemberian imunisasi pada anaknya (Rosalinda, 2010).

Hipotesis dalam penelitian ini yaitu (Ho) tidak terdapat hubungan pengetahuan tentang vaksin MR dan tingkat pendidikan orang tua terhadap keikutsertaan imunisasi MR di Desa Lam Bheu, Kecamatan Darul Imarah, Kabupaten Aceh Besar, (Ha) terdapat hubungan pengetahuan tentang vaksin MR dan tingkat pendidikan orang tua terhadap keikutsertaan imunisasi MR di Desa Lam Bheu, Kecamatan Darul Imarah, Kabupaten Aceh Besar

$$
\text { Rumusan masalah dalam }
$$

penelitian ini adalah apakah terdapat adanya hubungan antara pengetahuan orang tua tentang vaksin MR dan tingkat pendidikannya terhadap keikutsertaan dalam imunisasi MR kepada anaknya?

Penelitian ini bertujuan untuk mengetahui hubungan pengetahuan tentang vaksin MR dan tingkat pendidikan dengan keikutsertaan imunisasi MR pada orang tua.Untuk mengetahui tingkat pengetahuan serta tingkat pendidikan dan juga untuk mengetahui persentase keikutsertaan orang tua dalam imunisasi MR. Penelitian ini diharapkan dapat memberikan informasi tentang pengetahuan dan tingkat pendidikan terhadap keikutsertaan orang tua imunisasi MR.

\section{METODE}

Metode

penelitian ini menggunakan desain penelitian Observatik Analitik dengan pendekatan Cross Sectional.Populasi dalam penelitian ini adalah seluruh orangtua yang memiliki anak usia 9 bulan sampai dengan kurang dari 15 tahun di Desa Lam Bheu Kecamatan Darul Imarah Kabupaten Aceh Besar yang berjumlah 226 orang. Sampel dalam penelitian menggunakan teknik purposive sampling dimana sampel penelitian yaitu orangtua yang memiliki anak usia 9 bulan sampai dengan kurang dari 15 tahun dan memenuhi kriteria inklusi yang berjumlah 69 responden.

Variabel penelitian ini ada variable independent meliputi pengetahuan dan variabel dependent meliputi keikutsertaan imunisasi.Instrument pengumpulan data penelitiaan menggunakan kuesioner dalam bentuk multipel choice yang menyediakan beberapa alternatif jawaban.Lokasi penelitian dilakukan di Desa Lam Bheu Kecamatan Darul Imarah Kabupaten Aceh Besar. Waktu penelitian ini dilakukan pada bulan Maret-April 2019.

Analisis data menggunakan analisa univariat dan bivariat, analisis univariat untuk melihat distribusi dan frekuensi variabel dependent dan independent sedangkan analisis bivariat untuk mengetahui hubungan antara variabel dependent dan variabel independen yang dianalisis dengan uji Chi-Squre $\left(X^{2}\right)$ menggunakan program SPSSdengan nilai $a=0,05$, dengan ketentuan yang berlaku yaitu bila $p$ value $\leq$ a $(0,05)$, maka ada hubungan yang bermakna antara variabel independent dan variabel dependent. Bila $p$ value $\geq a(0,05)$ maka tidak ada hubungan yang bermakna antara varibel independent dan variabel dependent. 
HASIL

Berdasarkan hasil Tabel 1 di bawah ini diketahui bahwa distribusi frekuensi data responden berdasarkan usia orang tua berkisar pada umur 23 tahun sampai 49 tahun, dengan ratarata umur responden adalah 41 tahun.

Tabel 1. Distribusi Frekuensi Usia Orangtua yang Memiliki Anak Usia 9 Bulan Sampai dengan Kurang 15 Tahun di Desa Lam Bheu, Kecamatan Darul Imarah, Kabupaten Aceh Besar

\begin{tabular}{ccc}
\hline Minimum & Mean & Maksimum \\
\hline 23 tahun & 41 tahun & 49 tahun \\
\hline
\end{tabular}

Berdasarkan hasil Tabel 2 di bawah ini diketahui bahwa distribusi frekuensi data responden berdasarkan sumber informasi yang diperoleh oleh responden berasal dari Televisi sebanyak 8 orang $(11,6 \%)$, Internet sebanyak 6 orang $(8,7 \%)$, P.Kes sebanyak 22 orang $(31,9 \%)$, Teman sebanyak 16 orang $(23,2 \%)$, dan Spanduk sebanyak 17 orang $(24,6 \%)$.

Tabel 2. Distribusi Frekuensi Sumber Informasi Vaksin MR yang Diperoleh Orangtua yang Memiliki Anak Usia 9 Bulan-Kurang 15 Tahun di Desa Lam Bheu, Kecamatan Darul Imarah, Kabupaten Aceh Besar

\begin{tabular}{ccc}
\hline Sumber Informasi & Frekuensi & Persentase (\%) \\
\hline Televisi & 8 & 11,6 \\
Internet & 6 & 8,7 \\
Pelayanan Kes & 22 & 31,9 \\
Teman & 16 & 23,2 \\
Spanduk & 17 & 24,6 \\
Total & 69 & 100 \\
\hline
\end{tabular}

Berdasarkan hasil Tabel 3 di bawah ini diketahui bahwa distribusi frekuensi data responden berdasarkan keikutsertaan orang tua dalam imunisasi MR sanggat tinggi sebesar 51 $(73,9 \%)$ dan selebihnya masuk dalam kategori rendah sebesar $18(26,1 \%)$.

Tabel 3. DistribusiFrekuensi Keikutsertaan Orangtua Dalam Imunisasi MR terhadap Anaknya yang Berusia 9 Bulan-Kurang 15 Tahun di Desa Lam Bheu, Kecamatan Darul Imarah, Kabupaten Aceh Besar

\begin{tabular}{ccc}
\hline Keikutsertaan & Frekuensi & Persentase (\%) \\
\hline Tinggi & 51 & 73,9 \\
Rendah & 18 & 26,1 \\
\hline Total & 69 & 100 \\
\hline
\end{tabular}

Berdasarkan hasil Tabel 4 di bawah ini diketahui bahwa distribusi frekuensi data responden berdasarkan tingkat pendidikan orangtua pada tingkat Sarjana sebanyak 22 orang $(31,9 \%)$ dan tingkat pendidiakn SMA didapatkan sebanyak 47 orang $(68,1 \%)$. 
Tabel 4. Distribusi Frekuensi Tingkat Pendidikan Orangtua yang Memiliki Anak Usia 9 Bulan-Kurang 15 Tahun di Desa Lam Bheu, Kecamatan Darul Imarah, Kabupaten Aceh Besar

\begin{tabular}{ccc}
\hline Tingkat Pendidikan & Frekuensi & Persentase (\%) \\
\hline Sarjana & 22 & 31,9 \\
SMA & 47 & 68,1 \\
\hline Total & 69 & 100 \\
\hline
\end{tabular}

Berdasarkan hasil Tabel 5 di bawah ini diketahui bahwa distribusi frekuensi data responden berdasarkan pengetahuan orangtua tentang vaksin
MR didapatkan sebesar $44(63,7 \%)$ ini termasuk pengetahuan yang tinggi dan $25(36,3 \%)$ ini termasuk pengetahuan rendah.

Tabel 5. DistribusiFrekuensi Pengetahuan Orangtua yang Memiliki Anak Usia 9 Bulan-Kurang 15 Tahun tentang Vaksin MR di Desa Lam Bheu, Kecamatan Darul Imarah, Kabupaten Aceh Besar

\begin{tabular}{ccc}
\hline Pengetahuan & Frekuensi & Persentase (\%) \\
\hline Tinggi & 44 & 63,7 \\
Rendah & 25 & 36,3 \\
Total & 69 & 100 \\
\hline
\end{tabular}

Berdasarkan Tabel 6 di bawah ini diperoleh bahwa pengetahuan tinggi dengan tingkat keikutsertaan tinggi diperoleh sebanyak 42 orang $(95,5 \%)$ sedangkan untuk tingkat pengetahuan rendah keikutsertaan tinggi diperoleh sebanyak 9 orang (36\%). Hasil Uji Statistik menggunakan uji Chi-Square diperoleh bahwa terdapat hubungan yang signifikan antara pengetahuan dengan Keikutsertaan imunisasi MR dimana $p=0,000$ atau $p<0,005$.

Tabel 6. Hubungan Pengetahuan Orangtua tentang Vaksin MR terhadap Keikutsertaan Imunisasi MR di Desa Lam Bheu,Kecamatan Darul Imarah, Kabupaten Aceh Besar.

\begin{tabular}{|c|c|c|c|c|c|c|}
\hline \multirow{3}{*}{ Pengetahuan } & \multicolumn{4}{|c|}{ Keikutsertaan } & \multirow{3}{*}{ P-Value } & \multirow{3}{*}{$\begin{array}{c}\text { Odds Ratio } \\
\text { (OR) }\end{array}$} \\
\hline & \multicolumn{2}{|c|}{ Rendah } & \multicolumn{2}{|c|}{ Tinggi } & & \\
\hline & $\mathbf{N}$ & $\%$ & $\mathbf{N}$ & $\%$ & & \\
\hline Rendah & 16 & 64 & 9 & 36 & \multirow{3}{*}{0,000} & \multirow{3}{*}{0,027} \\
\hline Tinggi & 2 & 4,5 & 42 & 95,5 & & \\
\hline Total & 18 & 26,1 & 51 & 73,9 & & \\
\hline
\end{tabular}

Berdasarkan tabel 7 di bawah ini diperoleh bahwa tamatan pendidikan SMA dengan tingkat keikutsertaan tinggi diperoleh sebanyak 34 orang $(77,3 \%)$ sedangkan untuk tamatan Sarjana dengan tingkat keikutsertaan tinggi sebanyak 17 orang (72,3\%).
Hasil Uji Statistik menggunakan uji ChiSquare diperoleh bahwa tidak ada hubungan yang signifikan antara tingkat pendidikan dengan keikutsertaan imunisasi MR dimana $p=0,664$ atau $p>0,05$. 
Tabel 7. Hubungan Tingkat Pendidikan Orangtua terhadap Keikutsertaan Imunisasi MR di Desa Lam Bheu,Kecamatan Darul Imarah, Kabupaten Aceh Besar.

\begin{tabular}{|c|c|c|c|c|c|c|}
\hline \multirow{3}{*}{ Pendidikan } & \multicolumn{4}{|c|}{ Keikutsertaan } & \multirow{3}{*}{ P-Value } & \multirow{3}{*}{$\begin{array}{c}\text { Odds Ratio } \\
\text { (OR) }\end{array}$} \\
\hline & \multicolumn{2}{|c|}{ Rendah } & \multicolumn{2}{|c|}{ Tinggi } & & \\
\hline & $\mathbf{N}$ & $\%$ & $\mathbf{N}$ & $\%$ & & \\
\hline SMA & 13 & 27,7 & 34 & 77,3 & \multirow{3}{*}{0,664} & \multirow{3}{*}{0,769} \\
\hline Sarjana & 5 & 22,7 & 17 & 72,3 & & \\
\hline Total & 18 & 26,1 & 51 & 73,9 & & \\
\hline
\end{tabular}

\section{PEMBAHASAN}

Pengetahuan tentang vaksin MR merupakan satu diantara aspek penting sebagai pemahaman terhadap pentingnya dilakukan imunisasi MR. Minat keikutsertaan imunisasi MR yang tinggi didasarkan oleh pengetahuan orang tua tentang vaksin MR (Kusumoningtyas $\mathrm{R}$, Mudayati $\mathrm{S}$, Susmini, 2016). Apabila orang tua memiliki pengetahuan yang kurang terhadap bahayanya terserang penyakit campak dan rubella, maka orang tua tersebut akan membuat suatu keputusan yang salah terhadap kesehatan anaknya (Gahara, 2015).

Pengetahuan orang tua tentang vaksin MR sangatlah baik dan Keikutsertaan orang tua dalam imunisasi MR tinggi. Pada hasil pengukuran hubungan pengetahuan orang tua tentang vaksin MR dengan keikutsertaan imunisasi MR yang telah dilakukan dan dianalisis dengan menggunakan uji statistik Chi-Squre pada interval kepercayaan $95 \%$ dengan $p$-value $=0,05$ menunjukkan adanya hubungan antara pengetahuan orang tua tentang vaksin MR dengan keikutsertaan imunisasi MR dengan nilai $p$-value $0,000 \quad(p<0,05)$. Penelitian ini juga sejalan dengan penelitian Marlinta, adanya hubungan yang signifikan antara pengetahuan dengan minat keikutertaan vaksin MR di puskesmas Kartasuara dengan nilai $p$-value 0,016 $(\mathrm{p}<0,05) \quad$ (Marlinta, 2018). Tingkat pendidkan pada orang tua rata-rata tamatan SMA sebagian lagi adalah tamatan sarjana dan tingkat keikutsertaan imunisasi MR sangat tinggi. Pada hasil pengukuran hubungan tingkat pendidikan orang tua dengan keikutsertaan imunisasi MR yang telah dilakukan dan dianalisis dengan menggunakan uji statistik ChiSqure pada interval kepercayaan 95\% dengan $p$-value $=0,05$ menunjukkan tidak adanya hubungan antara tingkat pendidikan orang tua dengan keikutsertaan imunisasi MR dengan nilai $p$-value $0,664(p>0,05)$. Hal ini wajar terjadi karena terdapat beberapa faktor yang dapat menyebabkan pendidikan orangtua tidak mempunyai pengaruh terhadap keikutsertaan diantaranya seperti informasi yang mudah didapat baik dari media massa maupun kampanye, dan pengetahuan orangtua tidak berasal dari pendidikan formal saja. Penelitian ini sejalan dengan penelitian Gyuh Mustika Prabandari, tidak adanya hubungan yang signifikan antara tingkat pendidikan dengan minat keikutertaan vaksin MR di Desa Gumpang, Kecamatan Kartasuara, Kabupaten Sukoharjo dengan nilai $p$ value $0,262 \quad(p>0,05) \quad$ (Prabandari, 2018).

\section{KESIMPULAN}

Berdasarkan analisis data dan hasil penelitian yang telah dilakukan di Desa Lam Bheu, Kecamatan Darul Imarah, Kabupaten Aceh Besar didapatkan bahwa terdapat hubungan antara pengetahuan orang tua tentang vaksin MR dengan Keikutsertaan imunisasi MR, tetapi beda halnya pada tingkat pendidikan orang tua dengan 
keikutsertaan imunisasi MR dimana tidak terdapat hubungan antara tingkat pendidikan orang tua dengan keikutsertaan imunisasi MR.

\section{SARAN}

Berdasarkan hasil dan kesimpulan penelitian diatas, maka peneliti mencoba memberikan saran ataupun masukan, yakni sebagai berikut : Bagi peneliti di harapkan penelitian ini menjadi bahan bacaan dan acuan, serta penyempurnaan penelitian selanjutnya untuk menambah wawasan serta ilmu pengetahuan bagi peneliti, sehingga dapat mempertimbangkan variable lain, dan perlu dilakukan penelitian lebih lanjut dengan rancangan penelitian yang berbeda untuk mengetahui permasalahan yang lebih mendalam. Bagi institusi di harapkan agar lebih aktif lagi dalam mengsosialisasikan tentang vaksin MR, agar anak Indonesia dapat mencegah angka kesakitan dan kematian akibat penyakit infeksi virus campak dan rubella. Bagi penelitian lainya diharapkan pada penelitiannya jumlah sampel yang diperoleh lebih besar, sehingga hasil penelitian nantik dapat dimanfaatkan dengan baik sebagai informasi bagi orang lain. Bagi orangtua yang memiliki anak baik itu bayi atau balita sebaikknya di pertahankan dalam mengupgrade informasi kesehatan anak agar penyakit yang berbahaya dapat dicegah secepatnya.

\section{DAFTAR PUSTAKA}

Awam. (2017). Rubella \& Campak Penyebab Penyakit Berat Dan Kecacatan/Cacat Janin, pp. 1-31

Departemen Kesehatan RI. (2017). Imunisasi Measles Rubella Lindungi Anak Kita, Kementrian Kesehatan Republik Indonesia, pp. 8-9

Dinkes Aceh. (2018). Profil Kesehatan Provinsi Aceh 2018, Aceh

Ditjen P2P, K. R. (2018). Petunjuk Teknis Kampanye Imunisasi Measles Rubella (Mr), No 8(1), pp. 1-208
Gahara E, Saftarina F, Lisiswati R. (2015). Hubungan Tingkat Pengetahuan Ibu Dan Status Ekonomi Dengan Kelengkapan Imunisasi Wajib Pada Anak Usia 0-12 Bulan Di Puskessmas Sawah, Majority, PP. 4-9

Hidayat. (2018). Pengantar IImu Kesehatan Anak. Yogyakart, Salemba medika.

Kemenkes RI. (2018). Imunisasi Mr Penting Diberikan Untuk Melindungi Anak, pp. 1-2

Kemenkes RI. (2018). Strategi Imunisasi Massal Mr, pp. 1-2

Kusumoningtyas R, Mudayati S, Susmini. (2016). Hubungan Pengetahuan Ibu Tentang Imunisasi Anjuran Dengan Minat Melakukan Imunisasi Anjuran Pada Balita Di Poliklinik Imunisasi Rumah Sakit Panti Waluya Malang, Nurs News, PP. 1-2

Marlinta. (2018). Hubungan Pengetahuan tentang Vaksin $\mathrm{Mr}$ (Measles Rubella) Dan Tingkat Pendidikan Ibu Terhadap Minat Keikutsertaan Vaksinasi $\mathrm{Mr} \mathrm{Di}$ Puskesmas Kartasuara, No 1(2), pp. $1-15$

McGee, P. 2015. Measles, Mumps, and Rubella',Divers Equal Heal Care, No 10(3), pp. 123-5

Najah, L. (2017). Tingkat Pengetahuan Ibu Tentang Imunisasi Tambahan Mr (Measles Rubella) Pada Balita Di Puskesmas Kotagede I Yogyakarta, No 6(4), pp. 1-13

Prabandari GM, Musthofa SB, Kusumawati A. (2018). Beberapa Faktor Yang Berhubungan Dengan Penerimaan Ibu Terhadap Imunisasi Measles Rubella Pada Anak SD Di Desa Gumpang, Kecamatan Kartasuara, Kabupaten Sukoharjo, J Kesehat Masy, No 6(4), pp. 573-581

Puskesmas Darul Imarah Aceh Besar. (2018). Profil Kesehatan Provinsi Aceh Besar 2018, Aceh besar

Rosalinda. (2010). Cara Benar Merawat Anak. Yogyakarta, Nuha medika.

UNICEF. (2017) Polemik Vaksin MR di Aceh Belum Selesai. Alvailable at: https://www.unicef.org/indonesia 
/id/Preview_FA_UNICEF_MR_Pake t_Advokasi.REV27jul19.pdf,

diakses 7 Desember 2017

UNICEF. (2018). Imunisasi Massal Campak Rubella. Alvailable at: https://www.unicef.org/indonesia /id/Preview_FA_UNICEF_MR_Pake t_Advokasi.REV27Jun18.pdf.di, diakses 12 November 2017

Wawan. (2011). Teori \& Pengukuran Pengetahuan, Sikap dan Perilaku Manusia Dilengkapi Contoh Kuesioner. Yogyakarta, Nuha medika

WHO. (2017). Pedoman Kampanye Imunisasi Campak \& Rubella (Mr) Untuk Guru Dan Kader, pp. 1-4

WHO. (2018). Status Campak dan Rubella Saat Ini Di Indonesia, PP. 1-2. 